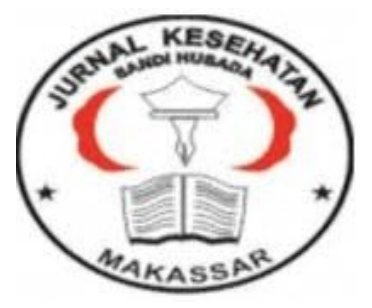

\author{
Jurnal Ilmiah Kesehatan Sandi Husada \\ hhttps://akper-sandikarsa.e-journal.id/JIKSH \\ Vol 11, No, 1, Juni 2020, pp; 135-144 \\ p-ISSN: 2354-6093 dan e-ISSN: 2654-4563 \\ DOI: $10.35816 /$ jiskh.v10i2.227
}

\title{
Tes Toleransi Glukosa Oral Pada Ibu Hamil Trimester II Dan III diPuskesmas Rawat Inap Kemiling Bandar Lampung
}

The Oral Glucose Tolerance Tests in Trimester II and III Pregnant Women at Puskesmas Inpatient Kemiling Bandar Lampung

\section{Mutia Hoirunnisah' ${ }^{1}$ Fonda Octarianingsih ${ }^{2}$, Festy Ladyani ${ }^{3}$, Bambang Kurniawan ${ }^{4}$}

\begin{tabular}{|c|c|}
\hline Artikel info & \\
\hline $\begin{array}{l}\text { Artikel history: } \\
\text { Received; } 15 \text { Maret } 2020 \\
\text { Revised:18 Maret } 2020 \\
\text { Accepted;21 Maret } 2020\end{array}$ & $\begin{array}{l}\text { Abstrak } \\
\text { Penelitian ini bertujuan untuk mengetahui gambaran tes } \\
\text { toleransi glukosa oral (TTGO) pada ibu hamil trimester II dan } \\
\text { III di Puskesmas Rawat Inap Kemiling Bandar Lampung } \\
\text { Tahun } 2019-2020 \text {. Jenis penelitian yang dilakukan adalah } \\
\text { deskriptif kualitatif. Sample pada penelitian ini menggunakan } \\
\text { teknik total sampling, dan didapatkan jumlah sample } \\
\text { sebanyak } 30 \text { responden. Diketahui hasil TTGO seluruh ibu } \\
\text { hamil trimester II dan trimester III dengan hasil kadar } \\
\text { glukosa pada trimester II terbanyak yaitu 101-110 mg/dl } 7 \\
\text { responden (46,7\%), pada trimester III yaitu } 70-90 \text { mg/dl } 5 \\
\text { responden (33,3\%), memiliki usia <35 tahun sebanyak } 12 \\
\text { responden (80\%) dan } 12 \text { responden (80\%). IMT normal } \\
\text { trimester II } 7 \text { responden (46.7\%), sedangkan pada trimester } \\
\text { III adalah overwight } 9 \text { responden (60\%). Riwayat paritas ibu } \\
\text { hamil terbanyak adalah primipara pada trimester II } 6 \\
\text { responden (40,0\%) dan trimester III } 7 \text { responden (46,7\%), } \\
\text { tidak memiliki riwayat abortus trimester II } 12 \text { responden } \\
\text { (80\%) dan } 13 \text { responden (86,7\%) trimester III. Tidak ada } \\
\text { riwayat bayi makrosomia trimester II } 15 \text { responden (100\%) } \\
\text { dan trimester III } 14 \text { responden (93.3\%). Tidak ditemukan } \\
\text { riwayat diabetes keluarga, riwayat diabetes gestasional dan } \\
\text { tekadan darah <140/90 pada ibu hamil trimester II dan III } \\
\text { sebanyak } 15 \text { responden (100\%). TTGO dapat menyimpulkan } \\
\text { suatu data mengenai resiko seseorang memiliki diabetes atau } \\
\text { sudah memiliki diabetes mellitus. } \\
\text { Abstract } \\
\text { This study aims to determine the description of an oral } \\
\text { glucose tolerance test (TTGO) in second and third trimester } \\
\text { pregnant women in Puskesmas Inpatient Kemiling Bandar }\end{array}$ \\
\hline
\end{tabular}


Lampung in 2019-2020. This type of research is descriptive qualitative. The sample in this study used a total sampling technique and obtained a total sample of 30 respondents. TTGO results are known for all pregnant women trimester II and trimester III with the results of the highest glucose levels in the second trimester is $101-110 \mathrm{mg} / \mathrm{dl} 7$ respondents (46.7\%), in the third trimester that is $70-90 \mathrm{mg} / \mathrm{dl} 5$ respondents $(33,3 \%)$, having age $<35$ years as many as 12 respondents (80\%) and 12 respondents (80\%). BMI normal trimester II 7 respondents (46.7\%), whereas in the third trimester were overweight 9 respondents (60\%). The most parity history of pregnant women was primipara in the second trimester 6 respondents (40.0\%) and third trimester 7 respondents (46.7\%), did not have a history of abortion trimester II 12 respondents (80\%) and 13 respondents (86.7\%) trimester III. There is no history of second-trimester macrosomia infants 15 respondents (100\%) and third trimester 14 respondents (93.3\%). No family history of diabetes was found, a history of gestational diabetes and blood pressure $<140 / 90$ in the second and third trimester pregnant women were 15 respondents (100\%). TTGO can conclude data about a person's risk of having diabetes or already having diabetes mellitus

Keywords:

Tes Toleransi Glukosa

Oral;

Ibu hamil Trimester II

dan III;

Diabetes Mellitus;

Gestasional
Coresponden author:

Email: mutiahoirunnisah22@gmail.com

artikel dengan akses terbuka dibawah lisensi CC BY -4.0

\section{Pendahuluan}

Diabetes melitus (DM) merupakan suatu kelompok penyakit metabolik dengan karakteristik hiperglikemia yang terjadi karena kelainan sekresi insulin, kerja insulin atau kedua-duanya (Purnamasari, 2015). Diabetes mellitus pada kehamilan gestational diabetes mellitus (GDM) adalah intoleransi glukosa yang ditemukan pertama kali pada masa kehamilan. Kriteria diagnosis DM pada kehamilan ditegakkan berdasarkan peremeriksaan oral glucose tolerance test (OGTT), dengan cara mengukur kadar glukosa pada saat puasa, 1 jam dan 2 jam setelah pemberian glukosa 75 gram. Glukosa 75 gram tersebut diberikan pada pagi hari yang sebelumnya pasien dipuasakan 8 jam.

Diagnosis GDM ditegakkan apabila ditemukan salah satu dari hasil nilai glukosa plasma berikut ini dipenuhi atau dilampaui, 1). Kadar gula dalam plasma saat puasa $>92 \mathrm{mg} / \mathrm{dl}$, 2). Kadar gula dalam plasma setelah 1 jam pemberian glukosa 75 gr $>180 \mathrm{mg} / \mathrm{dl}, 3)$. Kadar gula dalam plasma setelah 2 jam pemberian glukosa 75gr $>153 \mathrm{mg} / \mathrm{dl}$ (ADA, 2015). Penegakan diagnosis GDM di Indonesia dilakukan melalui pemeriksaan tes toleransi glukosa oral (TTGO), jika hasil TTGO gula darah puasa lebih dari $95 \mathrm{mg} / \mathrm{dl}$ dan gula darah 2 jam postprandial lebih dari $155 \mathrm{mg} / \mathrm{dl}$ maka ibu didiagnosis GDM (Abadi, 2010)

Berdasarkan Riskesdas tahun 2013, angka kejadian DM di Indonesia yang terdiagnosa 
pada usia lebih dari 15 tahun sebesar 2,1\%. Provinsi Lampung memiliki angka kejadian DM sebesar 0,8\% sedangkan Kota Bandar Lampung memiliki penderita DM terbanyak ketiga dengan angka kejadian 0,9\%. Prevalensi prediabetes di Indonesia pada tahun 2007 sebesar 10\% sedangkan prevalensi diabetes melitus gestasional di Indonesia sebesar 1,9\%- 3,6\% pada kehamilan umumnya (Soewondo, dkk, 2011). Diabetes gestasional juga dapat meningkatkan risiko bagi ibu 3-5\% untuk menjadi diabetes melitus gestasional di masa mendatang (Rahmawati, 2016).

Kehamilan adalah peristiwa yang didahului dengan bertemunya sel telur atau ovum dengan sel sperma. Proses kehamilan akan berlangsung selama kira-kira 10 bulan, atau 9 bulan kalender, atau 40 minggu, atau 280 hari yang dihitung dari hari pertama periode menstruasi terakhir (Wagiyo, dkk, 2016). Pada masa kehamilan terjadi perubahan fisiologis terhadap ibu hamil dimana akan lebih banyak memproduksi hormon-hormon seperti esterogen, progesteron, kortisol, prolaktin, dan plasenta laktogen yang akan berpengaruh kepada resistensi insulin, sehingga mengakibatkan kadar glukosa darah akan naik sedangkan insulin juga tetap tinggi. Keadaan meningkatnya kadar glukosa di dalam darah selama masa kehamilan disebut dengan diabetes melitus gestasional (IP.Suiroka, 2012). Diabetes melitus gestasional merupakan salah satu kehamilan yang beresiko. Melihat pentingnya tes toleransi glukosa oral pada ibu hamil, maka peneliti tertarik untuk melakuakan penelitian tentang "gambaran tes toleransi glukosa oral (TTGO) pada ibu hamil trimester II dan III di Puskesmas Rawat Inap Kemiling Kecamatan Kemiling Bandar Lampung".

\section{Metode}

Jenis penelitian yang dilakukan pada penelitian ini adalah deskriptif kualitatif, dengan tujuan untuk mengetahui gambaran tes toleransi glukosa oral (TTGO) pada ibu hamil trimester II dan III. Lokasi penelitian dilakukan di Puskesmas Rawat Inap Kemiling Kecamatan Kemiling Bandar Lampung pada bulan Desember 2019 s/d Janurari 2020. Populasi dalam penelitian ini adalah seluruh ibu hamil trimester II dan III yang memeriksakan diri di Puskesmas Rawat Inap Kemiling Kecamatan Kemiling Bandar Lampung. Pengambilan menggunakan teknik total sampling, dan didapatkan jumlah sample sebanyak 30 responden masing-masing 15 responden Trimester II (20-28 minggu) dan 15 responden Trimester III (28-37 minggu).

Kriteria inklusi pada penelitian ini yaitu bersedia menjadi responden dalam penelitian dan ibu hamil Trimester II (20-28 minggu) dan Trimester III (28-37 minggu). Serta dengan kriteria eksklusi yaitu Tidak bersedia menjadi responden dalam penelitian, memiliki riwayat mengonsumsi obat anti diabetik dan memiliki riwayat DM sebelumnya. Variabel Penelitian yang digunakan adalah tes tolenrasi glukosa oral (TTGO) pada Ibu hamil trimester II dan III.

\section{Hasil Dan Pembahasan}

Tabel 1. Distribusi Frekuensi dan Persentase Responden Berdasarkan Riwayat Diabetes Gestasional

\begin{tabular}{ccccc}
\hline \multirow{2}{*}{$\begin{array}{c}\text { Riwayat Diabetes } \\
\text { Gestasional }\end{array}$} & Frekuensi & $\begin{array}{c}\text { Persentase } \\
\mathbf{( \% )}\end{array}$ & Frekuensi & Persentase (\%) \\
\cline { 2 - 5 } & 0 & $0 \%$ & 0 & $0 \%$ \\
Ya & 15 & $100 \%$ & 15 & $100 \%$ \\
\hline Tidak & $\mathbf{1 5}$ & $\mathbf{1 0 0 \%}$ & $\mathbf{1 5}$ & $\mathbf{1 0 0 \%}$ \\
\hline Jumlah & & & &
\end{tabular}


Tabel 2. Distribusi Frekuensi dan Persentase Responden Berdasarkan Kadar Gula Darah Puasa

\begin{tabular}{ccccc}
\hline Kadar Gula Darah & \multicolumn{2}{c}{ Trimester II } & \multicolumn{2}{c}{ Trimester III } \\
\cline { 2 - 5 } Puasa (GDP) & Frekuensi & Persentase (\%) & Frekuensi & Persentase (\%) \\
\hline $50-60 \mathrm{mg} / \mathrm{dl}$ & 4 & $26,7 \%$ & 6 & $40 \%$ \\
$61-70 \mathrm{mg} / \mathrm{dl}$ & 5 & $33,3 \%$ & 3 & $20 \%$ \\
$71-80 \mathrm{mg} / \mathrm{dl}$ & 5 & $33,3 \%$ & 3 & $20 \%$ \\
$81-90 \mathrm{mg} / \mathrm{dl}$ & 1 & $6,7 \%$ & 3 & $20 \%$ \\
\hline Jumlah & $\mathbf{1 5}$ & $\mathbf{1 0 0 \%}$ & $\mathbf{1 5}$ & $\mathbf{1 0 0 \%}$ \\
\hline
\end{tabular}

Tabel 3. Distribusi Frekuensi dan Persentase Responden Berdasarkan Hasil TTGO

\begin{tabular}{ccccc}
\hline Kadar Gula & \multicolumn{2}{c}{ Trimester II } & \multicolumn{2}{c}{ Trimester III } \\
\cline { 2 - 5 } Darah TTGO & Frekuensi & Persentase (\%) & Frekuensi & Persentase (\%) \\
\hline $70-90 \mathrm{mg} / \mathrm{dl}$ & 2 & $13,3 \%$ & 5 & $33,3 \%$ \\
$91-100 \mathrm{mg} / \mathrm{dl}$ & 4 & $26,7 \%$ & 3 & $20 \%$ \\
$101-110 \mathrm{mg} / \mathrm{dl}$ & 7 & $46,7 \%$ & 3 & $20 \%$ \\
$111-125 \mathrm{mg} / \mathrm{dl}$ & 2 & $13,3 \%$ & 4 & $26,7 \%$ \\
\hline Jumlah & $\mathbf{1 5}$ & $\mathbf{1 0 0 \%}$ & $\mathbf{1 5}$ & $\mathbf{1 0 0 \%}$ \\
\hline
\end{tabular}

Hasil penelitan menunjukkan bahwa sebagian besar responden ibu hamil dalam penelitian ini memiliki kategori usia $<35$ tahun pada trimester II yaitu 12 responden (80\%) dan pada ibu hamil trimester III sebanyak 12 responden (80\%). Namun pada trimester II terdapat ibu hamil sebanyak 3 responden (20\%) dan sebanyak 3 responden (20\%) pada ibu hamil trimester III yang mempunyai faktor resiko diabetes gestasional pada rentang usia $>35$ tahun. Usia tersebut beresiko mengalami diabetes gestasional. Hal ini sejalan dengan penelitian Saldah, I.P (2012) yang berjudul "Faktor Resiko Kejadian Prediabetes I Diabetes Mellitus Gastasional di RSIA Siti Khadijah 1 Kota Makassar" bahwa ibu hamil yang berumur $\geq 35$ tahun berisiko 3,476 kali untuk menderita prediabetes/diabetes mellitus gestasional dibandingkan dengan umur ibu hamil $<35$ tahun dengan hasil uji statistik didapatkan nilai OR 3,476. Hal ini menunjukkan bahwa umur ibu hamil merupakan faktor risiko terhadap kejadian prediabetes/ diabetes mellitus gestasional.

Hal ini menunjukkan bahwa pada sebagian besar responden dikategorikan sebagai ibu hamil yang tidak berisiko tinggi. Umur ibu hamil berpengaruh terhadap terjadinya kehamilan resiko dimana umur $<20$ tahun alat reproduksi belum matang sempurna namun jika dideteksi secara dini dengan pemeriksaan yang rutin maka tidak akan terjadi resiko pada ibu hamil tersebut. Sedangkan ibu yang memiliki umur $>35$ tahun juga beresiko untuk melahirkan, dikarenakan kekuatan ibu hamil mengalami penurunan sehingga untuk mengedan tidak kuat lagi dan fungsi uterus atau system reproduksinya sudah mengalami berkurang. (Probowati, R, 2019)

Hasil penelitan menunjukkan bahwa sebagian besar IMT ibu hamil trimester II yang berjumlah 15 responden adalah Normal yaitu sebanyak 7 responden $(46,7 \%)$, Sedangkan pada ibu hamil trimester III yang paling banyak adalah Overwight $\left(25-29,9 \mathrm{~kg} / \mathrm{m}^{2}\right)$ sebanyak 9 responden (60,0\%). Hasil penelitian pada trimester II serupa dengan hasil penelitian oleh Rahmawati (2016) dengan judul skrining diabetes mellitus gestasional dan faktor yang mempengaruhinya, menyatakan sebagian besar responden memiliki IMT dengan kategori normal (66.7\%). Hal yang terjadi pada ibu hamil dengan IMT yang normal adalah pada proses metabolisme tubuh seperti peredaran aliran darah akan lebih lancar 
ibarat pipa air yang mengalir tidak terdapat sesuatu yang dapat menimbulkan sumbatan seperti lumut (kolesterol, trigliserida) sehingga dalam proses peredaran darah diharapkan lancar, apabila sudah lancar secara otomatis proses sirkulasi oksigen dalam pembuluh darah menjadi normal dan kerja jantung dan organ-organ lainnya juga tidak berat (Rahmawati.A, 2019).

Menurut Permatasari, dkk (2017), overweight adalah kelebihan berat badan dibandingkan dengan berat ideal yang dapat disebabkan oleh penimbunan jaringan lemak atau non lemak. Demikian juga dengan hasil penelitian pada trimester III ini sejalan dengan penelitan Permatasari, dkk (2017) yang berjudul "Hubungan Hipertensi dan Overweight dengan Kejadian Diabetes Mellitus Gestasional pada Ibu Hamil di Wilayah Kerja Kecamatan Sungai Kunjang Kota Samarinda" didapatkan bahwa hasil uji Chi - Square diperoleh nilai $P$ value sebesar 0.538 nilai ini lebih besar dari taraf signifikan 0.05 , sehingga dapat disimpulkan bahwa tidak ada hubungan antara overweight dengan kejadian diabetes melitus gestasional pada ibu hamil di kecamatan sungai kunjang tahun 2017. Namun overweight merupakan salah satu faktor risiko terjadinya diabetes melitus gestasional pada ibu hamil dengan OR 0,4 kali lipat untuk menderita diabetes mellitus gestasional dibandingkan ibu yang tidak memiliki riwayat overweigh.

Banyaknya ibu hamil dengan IMT $>25$ karena kesalahpahaman persepsi pada ibu hamil tentang jumlah porsi makan pada ibu hamil. Hal tersebut diakibatkan karena kurangnya pengetahuan ibu hamil karena pengaruh faktor pendidikan dan kurangnya informasi yang diterima ibu hamil mengenai pentingnya menjaga keseimbangan IMT. Hal lain yang berpengaruh terhadap kelebihan IMT ini adalah karena pola hidup yang tidak sehat seperti kurangnya aktivitas olahraga, gemar mengkonsumsi makanan dan minuman instan, merokok, pola tidur yang tidak seimbang dll. Oleh karena itu menurut peneliti jika ibu berencana untuk hamil sebaiknya menyeimbangkan berat badannya terlebih dahulu. Hal tersebut dapat dilakukan dengan mengubah pola hidup seperti banyak mengkonsumsi sayur dan buah,banyak mengkonsumsi air putih, menghindari makanan dan minuman instant, rajin berolahraga, menghindari tidur terlalu malam, tidak merokok, serta mengelola stress dengan baik. Apabila hal tersebut dilakukan dengan baik maka proses metabolisme yang terjadi dalam tubuh juga akan baik, peredaran darah menjadi lancar, pasokan oksigen ke otak tersuplai dengan baik sehingga dapat terhindar dari berbagai macam penyakit. BMI normal menurut WHO tahun 2011 adalah 18,5-24,9 jadi diharapkan para calon ibu hamil memiliki BMI yang seimbang sesuai imbauan WHO (Rahmawati.A, 2019).

Hasil penelitian menunjukkan bahwa sebagian besar tekanan darah ibu hamil saat dan sesudah puasa didapatkan $<140 / 90 \mathrm{mg} / \mathrm{dl}$, masing-masing tekanan darah ibu hamil trimester II saat dan sesudah puasa sebanyak 15 responden (100\%) dan ibu hamil trimester III sebanyak 15 responden (100\%). Menurut Zieva (2012) dalam Trisnawati (2013) beberapa literature mengaitkan hipertensi dengan resistensi insulin. Pengaruh hipertensi terhadap kejadian diabetes mellitus disebabkan oleh penebalan pembuluh darah arteri yang menyebabkan diameter pembuluh darah menjadi menyempit. Hal ini menyebabkan proses pengangkutan glukosa dari dalam darah menjadi terganggu.

Berdasarkan penelitan Permatasari, dkk (2017), tekanan darah tinggi jarang menimbulkan gejala dan cara untuk mengetahui adalah dengan mengukur tekanan darah. Hasil uji Chi-Square yang telah dilakukan, di peroleh nilai P-Value sebesar 0,252 nilai ini lebih besar dari taraf signifikan yaitu 0,05. Sehingga dapat disimpulkan bahwa tidak ada hubungan hipertensi dengan kejadian diabetes mellitus gestasional di kecamatan sungai kunjang kota samarinda dengan nilai signifikan lebih besar dari $5 \%(p=0,252>a=0,05)$. Sedangkan diabetes mellitus gestasional dengan faktor risiko hipertensi memiliki 
$\mathrm{OR}=4.667$ artinya ibu hamil yang memiliki faktor risiko hipertensi berisiko 4.6 kali lebih tinggi dibandingkan ibu hamil yang tidak memiliki faktor risiko hipertensi.

Hasil penelitian menunjukkan bahwa sebagian besar riwayat paritas ibu hamil trimester II dan III adalah Primipara yaitu masing-masing ibu hamil trimester II sebanyak 6 responden $(40,0 \%)$ dan ibu hamil trimester III sebanyak 7 responden $(46,7 \%)$. Berdasarkan penelitian yang dilakukan oleh Putri. M, dkk (2018) yang berjudul "Gambaran Kondisi Ibu Hamil dengan Diabetes Mellitus di RSD dr. Soebandi Jember Tahun 2013-2017" didapatkan bahwa kondisi ibu hamil dengan diabetes mellitus berdasarkan paritas paling banyak pada ibu hamil yang memiliki risiko rendah (paritas 2-3) yaitu sebanyak 15 pasien (79\%) dari total 19 pasien. Dari hasil penelitian tersebut dapat disimpulkan bahwa paritas tidak berpengaruh terhadap kejadian ibu hamil dengan diabetes mellitus. Makin tinggi paritas ibu maka makin kurang baik endometriumnya, hal ini diakibatkan oleh vaskularisasi yang berkurang ataupun perubahan atrofi pada desidua akibat persalinan yang lampau sehingga dapat mengakibatkan terjadinya komplikasi persalinan (Nora dan Mursyidah, 2015).

Hasil penelitian menunjukkan bahwa sebagian besar riwayat abortus pada ibu hamil trimester II yang paling banyak yaitu tidak memiliki riwayat abortus sebanyak 12 responden $(80 \%)$ dan pada ibu hamil trimester III sebanyak 13 responden $(86,7 \%)$. Abortus adalah berakhirnya suatu kehamilan pada atau sebelum kehamilan tersebut berusia 22 mingggu atau buah kehamilan belum mampu hidup diluar kandungan. Abortus selama kehamilan terjadi $15-20 \%$ dengan $80 \%$ diantaranya terjadi pada trimester pertama (<14 minggu) dan sebelum janin mencapai berat 5000 gram (Husin,2013).

Menurut World Health Organization (WHO, 2012) persentase kemungkinan terjadinya abortus cukup tinggi. Sekitar 15 - 40\% angka kejadian diketahui pada ibu yang sudah dinyatakan positif hamil dan $60-75 \%$ angka abortus terjadi sebelum usia kehamilan 12 minggu ( Kemenkes RI, 2014). Berdasarkan hasil penelitian yang dilakukan oleh Fitriani, R. (2017) responden dengan riwayat abortus memiliki risiko 2,270 kali lebih besar untuk mengalami diabetes mellitus gestasional dibanding dengan responden yang tidak memiliki riwayat abortus dengan uji Odds Ratio diperoleh nilai OR diperoleh nilai OR=2,270 (95\% CI: 0,867-5,942). Oleh karena nilai LL dan UL mencakup nilai satu dengan tingkat kepercayaan 95\%, maka nilai 2,270 dianggap tidak bermakna secara statistik atau riwayat abortus bukan merupakan faktor risiko kejadian diabetes mellitus gestasional. Abortus lebih banyak terjadi pada ibu yang memiliki usia beresiko 55,6\% (35 tahun) dibandingkan pada ibu yang memiliki usia tidak beresiko 10,8\% karena pada usia muda/remaja keguguran dapat terjadi disebabkan alat reproduksi belum matang dan belum siap untuk hamil (Rochmawati, 2013).

Hasil penelitian menunjukkan bahwa sebagian besar riwayat melahirkan bayi makrosomia adalah tidak memiliki riwayat melahirkan bayi makrosomia, pada ibu hamil trimester II sebanyak 15 responden (100\%) dan pada ibu hamil trimester III terdapat sebanyak 14 responden (93\%), terdapat 1 responden ibu hamil trimester III yang terdeteksi dalam riwayat makrosomia (6.7\%). Berdasarkan hasil penelitian yang dilakukan oleh Fitriani,R. (2017), dengan judul "Analisis Faktor Risiko Kejadian Diabetes Melitus Gestasional di Wilayah Kerja Puskesmas Kecamatan Somba Opu Kabupaten Gowa Tahun 2016" menunjukkan bahwa sebagian besar hasil analisis bivariat diperoleh nilai $\mathrm{OR}=6,680 \quad(95 \% \mathrm{CI}: 1,686-44,686)$. Dengan demikian responden dengan riwayat makrosomia memiliki risiko 6,680 kali lebih besar untuk mengalami diabetes mellitus gestasional dibanding dengan responden yang tidak memiliki riwayat makrosomia. Berdasarka pada hasil Riset Kesehatan Dasar (Riskesdas, 2018), persentase berat badan 
lahir anak dengan berat badan $>4000$ gram ada berkisar $(3,7 \%)$ dari jumlah kelahiran bayi nasional.

Pada kasus makrosomia yang menjadi penyebab adalah peningkatan kadar glukosa ibu sehingga mempengaruhi peningkatan kadar glukosa bayi dan bila kadar glukosa ibu meningkat maka glukosa tersebut akan diserap $80 \%$ oleh bayi melalui membran plasenta yang dimulai sejak usia kehamilan 8-10 minggu. Sehingga ibu yang memiliki riwayat pernah melahirkan bayi besar akan memiliki resiko 5-10 kali melahirkan bayi besar juga. Pada ibu hamil yang tidak memiliki riwayat melahirkan makrosomia berarti tidak terjadi pengendapan lemak di bahu dan badan yang dapat memicu terjadinya distosia bahu dan kadar glukosa pada ibu juga normal sehingga proses penyerapan kadar glukosa pada bayi juga normal sehingga tidak menyebabkan resiko terjadinya diabetes mellitus gestasional (Rahmwati. A, 2019).

Hasil penelitian menunjukkan bahwa sebagian besar riwayat diabetes pada keluarga pada ibu hamil trimester II dan III yaitu (100\%) tidak memiliki riwayat diabetes pada keluarga. Hasil penelitian ini sejalan dengan penelitian Rahmwati, A (2019) yang berjudul "Deskripsi Faktor Resiko Diabetus Mellitus Gestasional di Poli Kandungan RSD Kalisat Jember" didapatkan sebagian besar ibu hamil yang tidak beresiko diabetes mellitus gestasional karena tidak ada riwayat diabetes mellitus pada keluarga yaitu sebanyak 183 atau $90,10 \%$. Adanya riwayat diabetes mellitus gestasional dikehamilan sebelumnya dan riwayat diabetes mellitus pada keluarga merupakan salah satu faktor risiko terjadinya diabetes mellitus gestasional. Menurut global diabetes community (2016) jika salah satu dari orangtua menderita DM maka resiko untuk menderita DM pada anaknya adalah sebesar 15\%, namun jika kedua orangtua memiliki DM maka resiko untuk menderita DM meningkat menjadi 75\% (Pakasi, K. L, 2019). Hal ini sejalan dengan penelitian Fitriani. R, (2017), yang berjudul "Analisis Faktor Risiko Kejadian Diabetes Melitus Gestasional di Wilayah Kerja Puskesmas Kecamatan Somba Opu Kabupaten Gowa Tahun 2016" didapatkan bahwa ibu hamil dengan riwayat keluarga memiliki risiko 6,929 kali lebih besar untuk mengalami diabetes mellitus gestasional dibanding dengan responden yang tidak memiliki riwayat keluarga. Risiko untuk mendapatkan diabetes mellitus dari ibu lebih besar 10-30\% dari pada ayah dengan diabetes mellitus. Hal ini dikarenakan penurunan gen sewaktu dalam kandungan lebih besar dari ibu. Jika saudara kandung menderita diabetes mellitus maka risiko untuk menderita DM adalah $10 \%$ dan $90 \%$ jika yang menderita adalah saudara kembar identik.

Hasil penelitian menunjukkan bahwa sebagian besar riwayat diabetes gestasional pada ibu hamil trimester II dan III yaitu (100\%) tidak memiliki riwayat diabetes gestasional, masing-masing sebanyak 15 responden (100\%) pada trimester II dan 15 responden (100\%) pada trimester III. Dampak yang ditimbulkan oleh ibu penderita diabetes melitus gestasional adalah ibu berisiko tinggi terjadi penambahan berat badan berlebih, terjadinya preklamsia, eklamsia, bedah sesar, dan komplikasi kardiovaskuler hingga kematian ibu. Setelah persalinan terjadi, maka penderita berisiko berlanjut terkena diabetes tipe 2 atau terjadi diabetes gestasional yang berulang pada masa yang akan dating, sedangkan bayi yang lahir dari ibu yang mengalami diabetes gestasional berisiko tinggi untuk terkena makrosomia (Perkins, J. M, 2007). Berdasarkan hasil penelitian yang dilakukan oleh Hidayati,R. dkk (2018) yang berjudul "Perbedaan Penyulit pada Masa Perinatal Ibu dengan Riwayat Diabetes Mellitus Gestasional dan Obesitas di RSUD Kabupaten Kediri" menunjukkan bahwa dari 50 responden ibu dengan riwayat diabetes mellitus gestasional sebagian besar mengalami penyulit makrosomia (34\%).

Kadar gula darah digunakan untuk menegakkan diagnosis DM. Untuk penentuan diagnosis, pemeriksaan yang dianjurkan adalah pemeriksaan secara enzimatik dengan 
bahan darah plasma vena. Sedangkan untuk tujuan pemantauan hasil pengobatan dapat menggunakan pemeriksaan gula darah kapiler dengan glukometer (PERKENI, 2011). Peningkatan kadar glukosa darah yang signifikan terjadi pada saat memasuki trimester kedua kehamilan, yakni antara minggu ke 24-28 (Sari, 2014).

Berdasarkan hasil penelitian ditemukan pada pemeriksaan gula darah puasa yakni pada ibu hamil trimester II dengan hasil terbanyak adalah 61 - $70 \mathrm{mg} / \mathrm{dl}$ sebanyak 5 responden $(33,3 \%)$ dan $71-80 \mathrm{mg} / \mathrm{dl}$ sebanyak 5 responden (33,3\%), sedangkan pada ibu hamil trimester III kadar gula darah puasa yang paling banyak yaitu $50-60 \mathrm{mg} / \mathrm{dl}$ sebanyak 6 responden (40\%). Penelitian Ini sejalan pengan penelitian Wedanthi. I (2017) dengan judul "Kadar Glukosa Darah Puasa Pada Ibu Hamil Trimester II dan III di Pusat Kesehatan Masyarakat I Denpasar Selatan" dengan hasil pemeriksaan kadar glukosa darah puasa pada ibu hamil trimester II dan III di Puskesmas I Denpasar Selatan berkisar antara 66$120 \mathrm{mg} / \mathrm{dL}$ dengan rata-rata 83,7 mg/dL, diperoleh 28 orang $(84,85 \%)$ dengan kadar glukosa darah puasa $<95 \mathrm{mg} / \mathrm{dL}$ dan 5 orang $(15,15 \%)$ dengan kadar glukosa darah puasa $\geq 95 \mathrm{mg} / \mathrm{dl}$.

Kemudia hasil yang ditemukan peneliti berdasarkan kadar TTGO pada ibu hamil trimester II dengan hasil terbanyak adalah $101-110 \mathrm{mg} / \mathrm{dl}$ sebanyak 7 responden (46,7\%), sedangkan pada ibu hamil trimester III kadar gula darah TTGO yang paling banyak yaitu 70 - $90 \mathrm{mg} / \mathrm{dl}$ sebanyak 5 responden (33,3\%). Pada penelitian yang dilakukan oleh Ernawati, N. (2017) dengan judul "Faktor Pendukung Timbulnya Gestasional DM pada Ibu Hamil di BPS" didapatkan berdasarkan hasil pemeriksaan glukosa darah maka responden dibagi menjadi 2 kelompok yaitu kelompok beresiko jika hasil glukosa darah acak $>200$ $\mathrm{mg} / \mathrm{dl}$, kemudian kelompok beresiko selanjutnya akan dilakukan pemeriksaan glukosa darah puasa dan TTGO. Sedangkan pada kelompok yang tidak beresiko adalah kelompok dengan hasil pemeriksaan glukosa darah acak masih normal atau < 200mg/dL. Berdasarkan penelitian menunjukan bahwa responden kelompok resiko memiliki rerata glukosa 218,9 mg/dl, glukosa puasa 139,87 dan TTGO 155,4 sejumlah 15 responden $(50 \%)$.

Berdasarkan hasil penelitian yang telah dilakukan di Puskesmas Rawat Inap Kemiling Kecamatan Kemiling Bandar Lampung didapatkan bahwa tidak ada ibu hamil yang terdeteksi beresiko diabetes gestasional dikarenakan semua ibu hamil tidak memiliki kadar gula darah puasa $>95 \mathrm{mg} / \mathrm{dl}$ dan tidak memiliki kadar gula pada tes tolerasi glukosa oral (TTGO) >155 mg/gl. Dari penelitian yang telah dilakukan Paramitha,G.M (2014), yang berjudul "Hubungan aktivitas fisik dengan kadar gula darah pada pasien diabetes melitus tipe 2 di rumah sakit umum daerah karanganyar" didapatkan bahwa terdapat hubungan yang signifikan antara aktivitas fisik dengan kadar gula darah pada pasien diabetes melitus tipe 2 di Rumah Sakit Umum Daerah Karanganyar dengan $p=0,001$ dan $r=-0,433$. Pengaruh aktivitas fisik atau olahraga secara langsung berhubungan dengan peningkatan kecepatan pemulihan glukosa otot (seberapa banyak otot mengambil glukosa dari aliran darah). Saat berolahraga, otot menggunakan glukosa yang tersimpan dalam otot dan jika glukosa berkurang, otot mengisi kekosongan dengan mengambil glukosa dari darah. Ini akan mengakibatkan menurunnya glukosa darah sehingga memperbesar pengendalian glukosa darah (Barnes, 2012).

\section{Simpulan dan Saran}

Diketahui hasil TTGO seluruh ibu hamil trimester II dan trimester III dengan hasil kadar glukosa pada trimester II terbanyak yaitu $101-110 \mathrm{mg} / \mathrm{dl} 7$ responden (46,7\%), pada trimester III yaitu $70-90 \mathrm{mg} / \mathrm{dl} 5$ responden $(33,3 \%)$, memiliki usia $<35$ tahun sebanyak 12 responden (80\%) dan 12 responden (80\%). IMT normal trimester II 7 responden 
(46.7\%), sedangkan pada trimester III adalah overwight 9 responden (60\%). Riwayat paritas ibu hamil terbanyak adalah primipara pada trimester II 6 responden $(40,0 \%)$ dan trimester III 7 responden (46,7\%), tidak memiliki riwayat abortus trimester II 12 responden (80\%) dan 13 responden (86,7\%) trimester III. Tidak ada riwayat bayi makrosomia trimester II 15 responden (100\%) dan trimester III 14 responden (93.3\%). Tidak ditemukan riwayat diabetes keluarga, riwayat diabetes gestasional dan tekadan darah $<140 / 90$ pada ibu hamil trimester II dan III sebanyak 15 responden (100\%).

Diharapkan kepada Puskesmas untuk dapat melakukan pemeriksaan skrining Diabetes melitus gestasional ke dalam program standar pemeriksaan antenatal care (ANC) untuk ibu hamil, dan kepada praktisi kesehatan khususnya bidan yang bertugas untuk dapat aktif dalam memberikan pendidikan kesehatan bagi ibu hamil tentang DM Gestasional dan faktor risiko yang mempengaruhinya. Ibu hamil yang berusia $\geq 35$ tahun dapat melakukan rutin kontrol gula darah agar medeteksi faktor resiko kejadian diabetes melitus gestasional. Diharapkan masyarakat dapat secara mandiri mencari informasi penting terkait DM Gestasional, serta melakukan pemeriksaan gula darah untuk skrining DM Gestasional pada saat pemeriksaan kehamilan.

\section{Daftar Rujukan}

Abadi, A. (2010). Panduan penatalaksanaan kehamilan dengan diabetes mellitus Barnes, D. E. (2011). Program Olahraga Diabetes. Yogyakarta: Citra Aji Parama.

Ernawati, N. (2017). Faktor Pendukung Timbulnya Gestasional DM pada Ibu Hamil di BPS. Jurnal Kesehatan Hesti Wira Sakti, 5(2), 108-115.

Fitriani, R. (2017). Analisis Faktor Risiko Kejadian Diabetes Melitus Gestasional Di Wilayah Kerja Puskesmas Kecamatan Somba Opu Kabupaten Gowa Tahun 2016. Molucca Medica, 110-126.

Hidayati, R., Setyorini, D., \& Nuari, N. A. (2018). Perbedaan Penyulit pada Masa Perinatal Ibu dengan Riwayat Diabetes Mellitus Gestasional dan Obesitas di RSUD Kabupaten Kediri. JURNAL ILKES (Jurnal Ilmu Kesehatan), 9(2), 148-160.

Husin, F. (2013). Asuhan Kehamilan Berbasis Bukti. SagungSeto, Jakarta.

IP, Suioroka. (2012). Penyakit Degeneratif. Jakarta: PT Gramedia Pustaka Utama

Kemenkes, R. I. (2014). Profil kesehatan Indonesia tahun 2013. Jakarta: Kemenkes RI.

Nora, W. S. and Mursyidah, E. (2015) 'Faktor Risiko Kejadian Diabetes Mellitus Dalam Kehamilan Pada Ibu Hamil Di Rumah Sakit Ibu dan Anak tahun 2014', 67.

Notoatmodjo,S. (2012). Metodelogi Penelitian Kesehatan. Jakarta: Rineka Cipta

Pakasi, K. L. (2019). Hubungan Persepsi Ibu Hamil Dengan Perilaku Diabetes Mellitus Gestasional Di Puskesmas Pamulang Tangerang Selatan Tahun 2019 (Bachelor's thesis, UIN Syarif Hidayatullah Jakarta-FIKES).

Paramitha, G. M. (2014). Hubungan aktivitas fisik dengan kadar gula darah pada pasien diabetes melitus tipe 2 di rumah sakit umum daerah karanganyar (Doctoral dissertation, Universitas Muhammadiyah Surakarta).

Permatasari, I. I. M., \& Susanti, E. W. (2017). Hubungan Hipertensi dan Overweight dengan Kejadian Diabetes Mellitus Gestasional pada Ibu Hamil di Wilayah Kerja Kecamatan Sungai Kunjang Kota Samarinda.

PERKENI, K. P. (2011). Pencegahan Diabetes Melitus Tipe II di Indonesia, Jakarta: PB.

Perkins, J. M., Dunn, J. P., \& Jagasia, S. M. (2007). Perspectives in gestational diabetes mellitus: a review of screening, diagnosis, and treatment. Clinical Diabetes, 25(2), 57-62.

Probowati, R., \& Sulastri, S. K. (2019). Gambaran Kehamilan Resiko Di Puskesmas Grogol Sukoharjo (Doctoral dissertation, Universitas Muhammadiyah Surakarta). 
Purnamasari, D. (2015). Diagnosis dan Klasifikasi Diabetes Melitus. In Setiati dkk (ed). Buku Ajar Ilmu Penyakit Dalam Jilid II Edisi VI. Jakarta: FKUI, hal: 2325

Putri, M. D. M. T., Wahjudi, P., \& Prasetyowati, I. (2018). Gambaran Kondisi Ibu Hamil dengan Diabetes Mellitus di RSD dr. Soebandi Jember Tahun 2013-2017 (Description of Pregnant Women Condition with Diabetes Mellitus in RSD dr. Soebandi Jember on 2013-2017). Pustaka Kesehatan, 6(1), 46-52.

Rahayu, A., \& Rodiani, R. (2016). Efek Diabetes Melitus Gestasional terhadap Kelahiran Bayi Makrosomia. Jurnal Majority, 5(4), 17-22.

Rahmwati, A. (2019). Deskripsi Faktor Resiko Diabetus Mellitus Gestasional Di Poli Kandungan RSD Kalisat Jember. Jurnal Kesehatan dr. Soebandi, 7(2), 98-105

Rahmawati, F., Natosba, J., \& Jaji, J. (2016). Skrining Diabetes Mellitus Gestasional dan Faktor Risiko yang mempengaruhinya. Jurnal Keperawatan Sriwijaya,3(2), 3343.

Riskesdas, H. (2018). pdf. Riset Kesehatan Dasar 2018.

Rochmawati, P. N., Sulastri, S. K., Zulaicha, E., \& Kp, S. (2013). Faktor-Faktor Yang mempengaruhi Abortus di Rumah Sakit Umum Pusat DR. Soeradji Tirtonegoro Klaten (Doctoral dissertation, Universitas Muhammadiyah Surakarta).

Saldah, I.P., Wahiddun,. Sidik, D. (2012). Faktor Resiko Kejadian Prediabetes I Diabetes Mellitus Gastasional di RSIA Siti Khadijah 1 Kota Makassar

Sari, K. (2014). Pengaruh Diabetes pada Kehamilan.

Soewondo, P., \& Pramono, L. A. (2011). Prevalence, characteristics, and predictors of prediabetes in Indonesia. Medical Journal of Indonesia, 20(4), 283-94.

Trisnawati, S. K., \& Setyorogo, S. (2013). Faktor risiko Kejadian diabetes melitus tipe II di puskesmas kecamatan cengkareng Jakarta Barat Tahun 2012. Jurnal Ilmiah Kesehatan, 5(1), 6-11.

Wagiyo, Putrono. (2016). Asuhan Keperawatan Antenatal, Intranatal dan Bayi Baru Lahir Fisiologis dan Patologis. Jakarta: Andi

Wedanthi, I. G. A., Putri, I. G. S. D., \& Krisna, L. A. W. (2017). Kadar Glukosa Darah Puasa Pada Ibu Hamil Trimester II Dan III Di Pusat Kesehatan Masyarakat I Denpasar Selatan, Vol 5, No 2

WHO. (2012). Infant \& Maternal Mortality. 